\title{
Morphological characterization of elite cacao trees (Theobroma cacao L.) in Tumaco, Nariño, Colombia
}

\section{Caracterización morfológica de árboles élite de cacao (Theobroma cacao L.) en Tumaco, Nariño, Colombia}
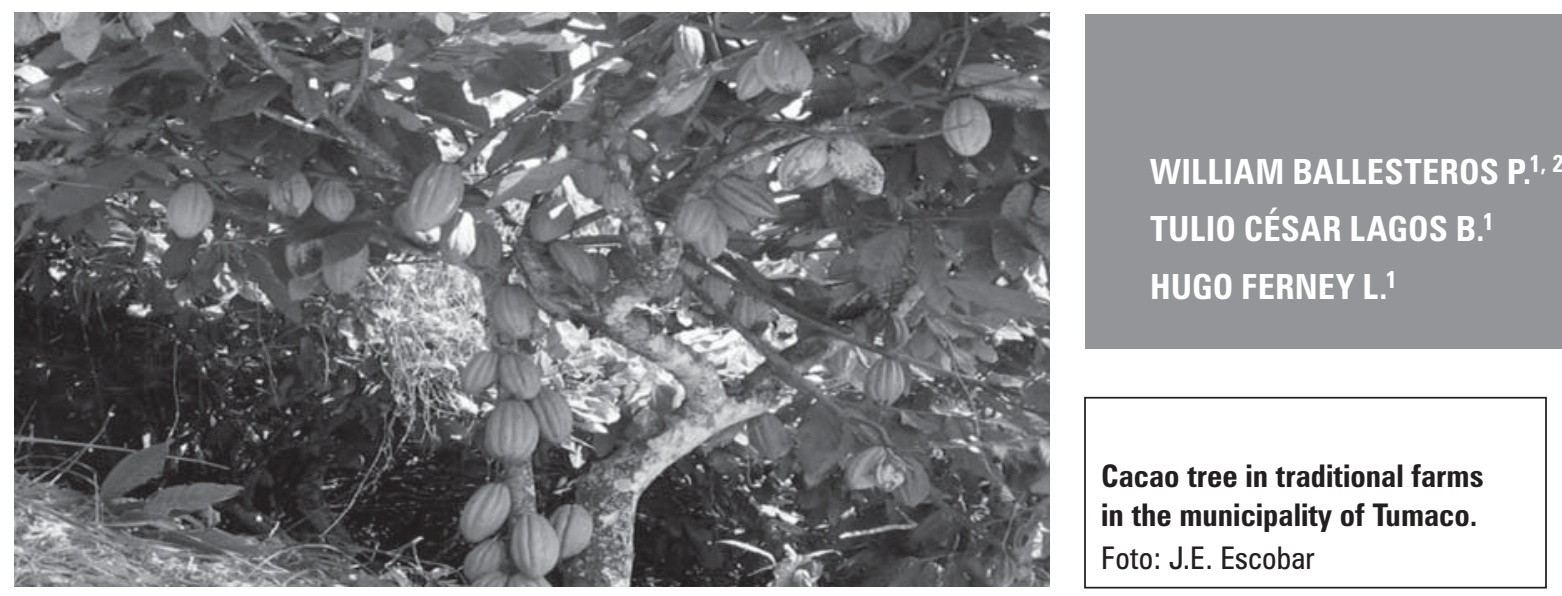

\section{ABSTRACT}

The cacao has become an essential part of the fight against the effects of illegal crops and rural poverty in Colombia. Because of their bromatological characteristics, cocoa beans are preferred in markets. However, there are few studies on the variability of the regional genotypes. The goal of this study was to characterize the cacao trees in Tumaco, Nariño (Colombia) and establish their morpho-agronomic variability. Plant collections were conducted in five production zones of the municipality between 0 to $270 \mathrm{~m}$. On each farm, the productivity and plant health variables were recorded for the outstanding plants. The characterization was carried out using a principal component analysis (PCA), multiple correspondence analysis (MCA) and cluster analysis. In the PCA, the first five components explained $70.2 \%$ of the variation. The first three components were characterized by productivity, while the last two components showed a low pod and grain index. In the MCA, the first three factors expressed 39.5\% of the variation. The first three corresponded to the cundeamor cacao, acute pod apex, absence of anthocyanin in ripe fruits, without notable pulvinus, staminodes without anthocyanins, and moderately susceptible to Moniliophthora perniciosa. The last two components reported tolerance to $M$. roreri and Crinnipellis perniciosa, intense anthocyanin pigmentation on the floral buttons and Angoleta-shaped fruit. The selected genotypes showed important characteristics that must be analyzed with molecular and sensorial analyses.

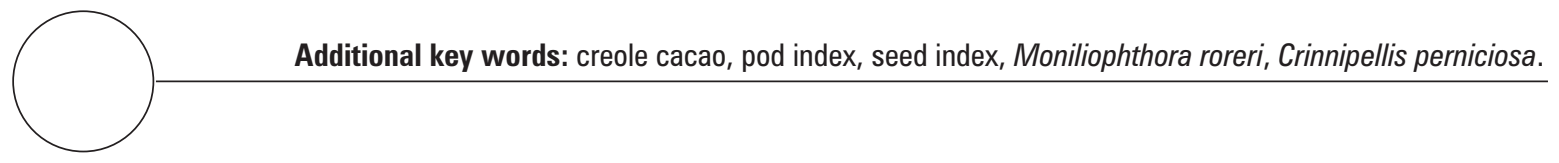

Facultad de Ciencias Agrícolas, Universidad de Nariño, San Juan de Pasto (Colombia).

2 Corresponding author.wballesterosp@gmail.com 


\section{RESUMEN}

El cacao se ha convertido en un fundamento para contrarrestar el efecto de los cultivos de uso ilícito y la pobreza rural. Debido a sus características bromatológicas, es preferido en el mercado nacional e internacional. Sin embargo, existen muy pocos estudios acerca de la variabilidad de los genotipos regionales. El objetivo del estudio fue caracterizar árboles de cacao en Tumaco, Nariño (Colombia) y establecer su grado de variabilidad morfoagronómica. Las colectas se realizaron en cinco zonas productivas del municipio entre 0 a $270 \mathrm{msnm}$. En cada finca se registraron variables de productividad y sanidad en las plantas más sobresalientes. Esta caracterización se realizó a través de análisis de componentes principales, correspondencias múltiples y agrupamientos. En ACP, los cinco primeros componentes explicaron el 70,2\% de la variación. En los tres primeros se caracterizan por tener con buenas características productivas, mientras que en el restose muestran bajos índices de mazorca y grano. En el MCA, los tres primeros factores expresaron el 39,5\% de la variación. Los tres primeros correspondieron al cacao cundeamor, ápice de mazorca agudo, ausencia de antocianina en frutos verdes, sin pulvinus notable, estaminoide sin antocianina, y moderadamente susceptibles a Moniliophthora perniciosa. Los dos últimos reportaron tolerancia a $M$. roreri y Crinnipellis perniciosa, intensa pigmentación de antocianina en los botones florales y fruto Angoleta. Los genotipos seleccionados reportaron importantes características las cuales deben ser analizadas mediante un análisis moleculares y sensoriales.

Palabras clave adicionales: genotipo criollo, índice de mazorca, índice de semilla, Moniliophthora roreri, Crinnipellis perniciosa.

Fecha de recepción: 25-09-2015

Aprobado para publicación: 20-11-2015
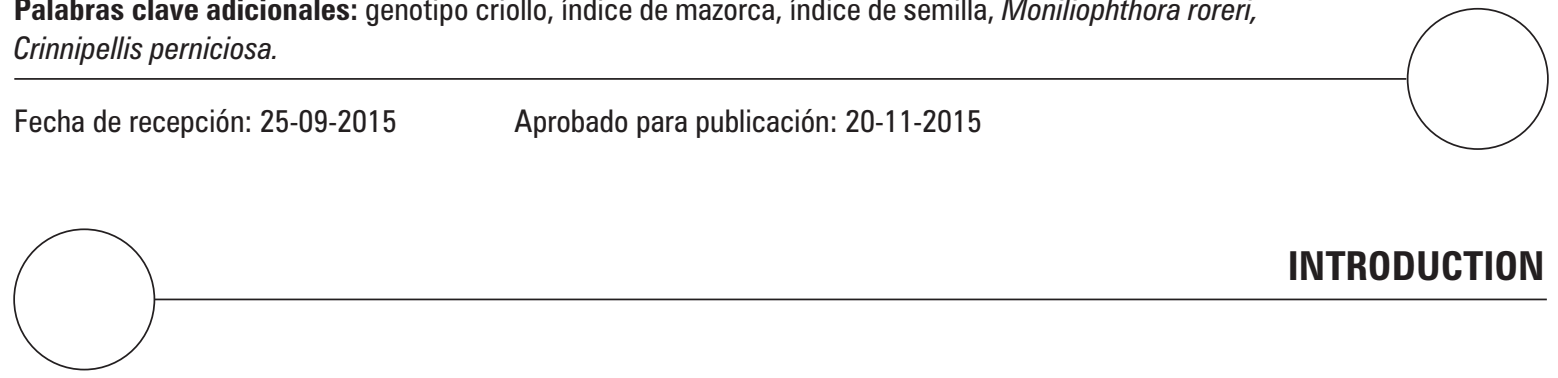

INTRODUCTION

The cacao plant (Theobroma cacao L.) belongs to the Malvaceae family and Malvales order and is one of the 22 species of the Theobroma genus (Arguello et al., 1999; De Almeida and Valle 2007). It is thought to have originated from the upper Amazon Basin (Soria, 1966; Zhang et al., 2008, 2012) and then to have spread to the tropical lowland areas. T. cacao is grown mainly between $20^{\circ} \mathrm{LN}$ and $20^{\circ} \mathrm{LS}$. However, the best plantations are located between $10^{\circ} \mathrm{LN}$ and $10^{\circ} \mathrm{LS}$ (Motamayor et al., 2002). In the Americas, T. cacao is grown from southern Mexico to Brazil and Bolivia (Clement et al., 2010). Tropical countries are the principal cacao growers. Africa, Asia, Oceania, and Latin America are the largest cacao producers. In contrast, cacao manufacturers are located in Europe and North America (ICCO, 2014).

Classifications based on where cacao is grown have divided the cacao genotypes into variet- ies, cultivars, types, or populations (Chessman, 1944; Thomas et al., 2012). Morphological descriptors are useful because they can help select the best accessions for breeding programs (Engels et al.,1980). Phenotypic characterization of the species, usually conducted by gene banks, involves leaf, flower, pod, and seed descriptors (Bekele and Bekele, 1996, Engels et al.,1980). The phenotypic appearance of cacao pods plays an important role in the definition of types and populations. Considerable variation is seen in fruits and seeds (Efombagn et al., 2009).

Studies on morphological diversity have been carried out on flowers, fruits, and leaves of accessions from cacao germplasm (Engels, 1986; Ayestas et al., 2013), which revealed the existence of two morphological groups: Criollo/Trinitario and Forastero, with variation between the two groups due to several genetic mixtures among the 
genotypes (Motilal et al., 2010). The classification reported by Engels (1986) was confirmed later by N'Goran (1994), using seed and pod characteristics. However, recent studies from Motamayor et al. (2008) questioned the existence of only these two genetic groups, and instead they proposed 10 genetic clusters. Flower trials used earlier by Enríquez and Soria (1967), and more recently by Lachenaud et al. (1999), allowed for the detection of great variability among cacao cultivars. All of these results indicate that morphological markers could be used to structure the diversity of different populations and avoid misleading classifications (Efombagn et al., 2009).

Another important factor for characterizing cacao genotypes is market preferences. Although the cacao crops in Tumaco are not exempt from the global productivity constraints experienced by global cacao crops (ICCO, 2014), their grains are endowed with an exceptional flavor and aroma that contrast with other National and International genotypes. Characteristics such as fruity and flowery aromas and flavor with nutty malt notes distinguish Tumaco cacao crops from other cacaos in the world (Casa Luker, 2012).

The cacao from Tumaco has been positioned in Europe by local manufacturers and labeled "CacaoTumaco" due to its high quality (Aranzazu and Agudelo, 2009). Despite these exceptional characteristics, foreign cacao genotypes could negatively affect the quality of these local genotypes.

For example, Venezuela was classified for a long time as an exclusive producer of fine and aroma creole cacao (ICCO, 2016), but the introduction of more resistant and productive foreign materials deteriorated the quality of the regional cacao (Cartay, 1997). In Tumaco, foreign cacao genotypes, such as CCN 51 and others, with low quality but high productivity can erode the distinctive characteristics of the traditional varieties. This is important and highlights the fact that these genotypes from Tumaco were classified as Fine Flavor by ICCO in 2011.
Escobar (2008) reported the existence of promising genotypes with high quality and visual resistance to frosty pod rot or moniliasis disease (Moniliophthora roreri (Stahel) Aime \& Phillips-Mora) and witches' broom disease (Crinnipellis perniciosa (Stahel) Singer). These facts call for attention and open the door for investigating these traditional cacao genotypes in Tumaco.

In this regard, it is important to improve the situation of the cacao crops from this region, encourage production of regional genotypes, increase their productivity, and maintain the quality of local genotypes.

For the reasons explained above, it is necessary to develop programs focused on preserving the criollo cacao, identifying promising genotypes, and establishing a breeding program to ensure the persistence of their distinctive characteristics. The aim of this study was to morphologically characterize cacao genotypes in the municipality of Tumaco, based on the descriptors proposed by International Cacao Biodiversity and adjusted by Engels et al. (1980).

\section{MATERIALS AND METHODS}

\section{Location}

This research was carried out on cacao farms located in Tumaco, Colombia, at 01 ${ }^{\circ} 39^{\prime} 47.8^{\prime \prime} \mathrm{LN}$ and $078^{\circ} 43^{\prime} 53.4^{\prime \prime} \mathrm{LW}$ to $01^{\circ} 42^{\prime} 57.1^{\prime \prime} \mathrm{LN}$ and $78^{\circ} 28^{\prime} 16$, 19 " LW. The genotype samples were collected in the villages of San Luis Robles, Mascarey, Carretera, and in the river basin of Rosario, Mejicano, and Chagüí (figure 1). The region was classified as tropical rainforest (bh-T) by Holdridge (1987). The farms were located in an alluvial landscape with altitudes ranging from 0 to 270 $\mathrm{m}$ a.s.1., mean annual precipitation of $2,800 \mathrm{~mm}$, mean annual temperature of $26^{\circ} \mathrm{C}, 88 \%$ relative humidity, and direct sunshine hours of $1,000 \mathrm{~h}$ year $^{-1}$ (Vallejo and Peña, 2006). 


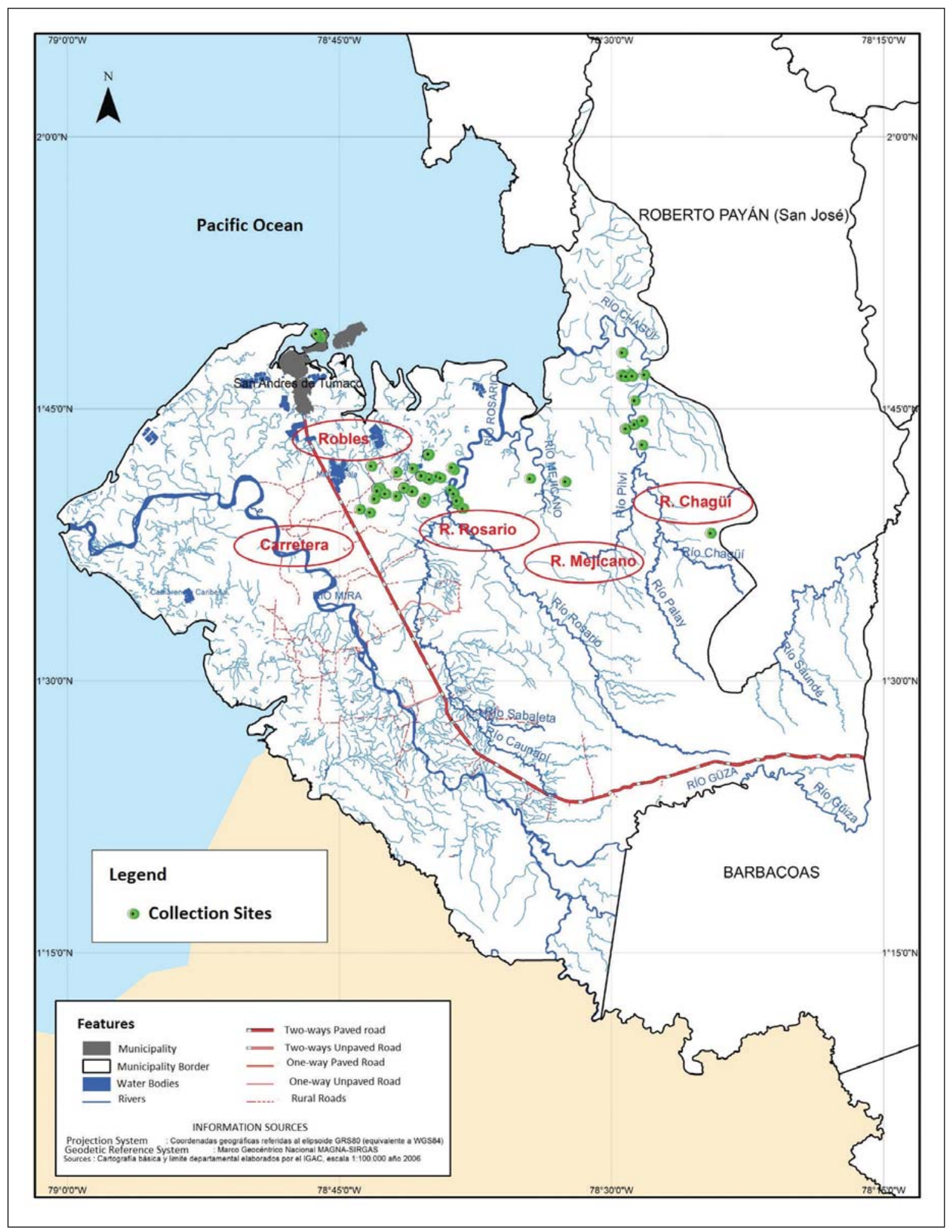

Figure 1. Location of the cacao production zones and the collection sites in Tumaco, Colombia. Source: Ballesteros (2011). 


\section{Cacao crops description}

The cacao plantations consisted of 'historical trees' or plants that have been maintained by farming family in traditional crop systems for at least two generations and are still classified as productive (Morillo et al., 2014). The cacao crop systems are carried out by smallholder farmers who rely on proceeds from the sale of cocoa beans as a major source of family income. On these farms, 102 cacao trees were morphologically characterized. These trees were grown in traditional production systems (Preciado et al., 2011), containing in most cases plantain, fruit and woody trees, as well as some food crops (such as annatto and yucca, among others). Cacao crops are specifically used as a cash crop. These cacao trees were more than 40 years old, taller than $8 \mathrm{~m}$ and $90 \%$ of them were affected by $M$. roreri and C. perniciosa. In Tumaco, these constraints have reduced the productivity of cacao to $278 \mathrm{~kg} \mathrm{ha}^{-1}$ (Consejo Regional Cacaotero, 2006).

\section{Selection of genotypes}

Cacao farmers identified their better trees based upon the following characteristics: (1) cacao trees older than 15 years, (2) productivity higher than 50 pods/tree-year and (3) tolerance to $M$. roreri and $C$. perniciosa. These trees were verified by experts and then evaluated based on the following indexes: (1) more than 60 pods per tree before the main harvest, (2) high blossom and good flower distribution in the main trunk and primary branches, (3) low incidence of $M$. roreri and C. perniciosa, (4) good phenotypic characteristics, (5) and complete competence with neighboring cacao trees.

The selected trees were labeled, georeferenced, and then morphologically characterized with the cacao morphological descriptors proposed by CATIE (Tables 1 and 2), based on Engels and Bartley (1980).

Table 1. Description of the quantitative morphological variables recorded in 102 T. cacao L. genotypes in Tumaco, Colombia.

\begin{tabular}{|l|l|l|}
\hline Variable number & Code & \multicolumn{1}{c|}{ Characteristic } \\
\hline 3 & LH & Leaf length(cm) \\
\hline 4 & AH & Leaf width (cm) \\
\hline 5 & RLAH & Leaf width/length ratio \\
\hline 9 & CR & Number of flower clusters per branch (cm) \\
\hline 10 & FC & Number of flowers per cluster \\
\hline 14 & LE & Staminode length (cm) \\
\hline 19 & LF & Pod length (cm) \\
\hline 20 & AF & Pod width (cm) \\
\hline 21 & RLAF & Pod width/length ratio \\
\hline 22 & GC & Shell thickness (cm) \\
\hline 25 & LA & Length of the pod edge (cm) \\
\hline 26 & PFG & Fresh grain green weight $(\mathrm{g})$ \\
\hline 27 & PSG & Dry grain weight (g) \\
\hline 28 & LG & Grain length (cm) \\
\hline 29 & AG & Grain width (cm) \\
\hline 31 & CGM & Grain number per pod \\
\hline
\end{tabular}

Source: Engels and Bartley (1980) 


\begin{tabular}{|c|c|c|}
\hline Variable & Characteristic & Modality \\
\hline 1 & Plant architecture & 1. Erect, 2. Intermediate, 3. Pendulous \\
\hline 2 & Plant vigor & 1. Weak, 2. Intermediate, 3. Vigorous \\
\hline 6 & Leaves base & 1. Acute, obtuse, rounded, cordate \\
\hline 7 & Leaves apex & 1.Acute, 2.Acuminate short, 3.Acuminate long \\
\hline 8 & Leaves petiole & 1. Non-visible pulvinus, 2. Visible Pulvinus \\
\hline 11 & Flowering pattern & 1.Continuous with peaks, 2.Non-continuous \\
\hline 12 & Color of floral peduncle & 1. Green, 2. Green with reddish pigmentation, 3. Reddish \\
\hline 13 & Anthocyanin on the floral bud & 1. Absent, 2.Light presence, 3. Intense pigmentation \\
\hline 15 & Anthocyanin on the staminode & 1. Absent, 2. Intermediate pigmentation, 3. Intense pigmentation \\
\hline 16 & Pot form & 1. Cundeamor, 2. Angoleta, 3. Amelonada, 4. Calabacillo, 5. Other \\
\hline 17 & Bottle-shaped basal constriction of the pod & $\begin{array}{l}\text { 1. Absent, 2. Presence of light neck, 3. Intermediate neck, 4. Neck } \\
\text { well marked }\end{array}$ \\
\hline 18 & Pod apex form & 1. Attenuate, 2. Acute, 3. Obtuse, Rounded, 4. Other \\
\hline 23 & Color of unripe pod surface & 1. Green, 2. Red, 3. Other \\
\hline 24 & Anthocyanin on the ripe pods & 1. Absent, 2. Intermediate, 3. Intense \\
\hline 30 & Seed form on the longitudinal cut & 1. Flattened, 2. Ovoid, 3. Cylindrical \\
\hline 32 & Seed color & 1. White, 2. Intermediate violet, 3. Violet \\
\hline 33 & Reaction to pod rot & $\begin{array}{l}\text { 1. Susceptible, 2. Moderately susceptible, 3. Moderately resistant, } \\
\text { 4. Resistant }\end{array}$ \\
\hline 34 & Reaction to witches' broom & $\begin{array}{l}\text { 1. Susceptible, 2. Moderately susceptible, 3. Moderately resistant, } \\
\text { 4. Resistant }\end{array}$ \\
\hline
\end{tabular}

Source: Engels and Bartley (1980)

\section{Statistical analysis}

The data were processed in a double-entry matrix in Excel using variables reported in tables 1 and 2 . The data on quantitative and qualitative characteristics were statistically analyzed based on the multiple correspondence analysis (MCA), principal component analysis (PCA) and cluster analysis, using SPAD version 3.5.

\section{RESULTS}

\section{Principal components analysis (PCA)}

The first five components explained $70.17 \%$ of the total variation. The first, second and third components accounted for $23.91 \%, 15.14 \%$ and $11.24 \%$, respectively. The estimates of the principal components eigen values are displayed in table 3 .

Table 3. Principal components and explained variance in the PCA.

\begin{tabular}{|c|c|c|c|}
\hline Component & Principal components & Explained variance (\%) & Cumulative variance (\%) \\
\hline 1 & 3.83 & 23.91 & 23.91 \\
\hline 2 & 2.42 & 15.14 & 39.06 \\
\hline 3 & 1.8 & 11.24 & 50.29 \\
\hline 4 & 1.7 & 10.49 & 60.78 \\
\hline 5 & 1.5 & 9.39 & 70.17 \\
\hline
\end{tabular}


The variables with higher correlation coefficients and major contributors to the formation of the first factor were: LF (0.66), LG (0.65), PFG (0.63), LAF (0.62) and AH (0.58) (table 4).

The second factor was composed of variables related to the reproductive structures: LAF (0.69), AF (0.65), FC (-0.61), AF (0.57) and CR (-0.50). The third component consisted of the width of the leaves and grains: RLAH (-0.55), AH (0.58) and AG (-0.58). The fourth component was grouped variables, which were related to the pod and grain appearances: RLAF (-0.64), RLAH $(-0.50)$ and PSG (0.50). Finally, the fifth component was composed of variables related to pod characteristics: GC (0.68) and PSG (-0.54).

\section{Hierarchical classification of the genotypes based on the PCA}

The dendrogram clearly defined interspecific differences in the distribution of the quantita- tive traits, which was reflected in the obtained rankings and the separation of the genotypes (figure 2). This dendrogram identified five major groups comprised of accessions with similar characteristics.

The first group (G1) had 38 genotypes, which represented $37.25 \%$ of the population. They were characterized by thicker and larger grains $(1.39 \mathrm{~cm}$ vs. $1.16 \mathrm{~cm}$ and 2.98 vs. $2.78 \mathrm{~cm}$, to be read as sampled mean $v$ s. population mean). This group also showed larger pods (9.97 vs. $9.53 \mathrm{~cm}$ ) and higher fresh (5.21 vs. $4.92 \mathrm{~g})$ and dry (1.38 vs. $1.35 \mathrm{~g}$ ) weights of the seeds. However, this group showed a lower number of flowers per inflorescence and number of inflorescences per branch.

The second group (G2) had 20 genotypes, containing $19.6 \%$ of the population. This group had a larger number of flowers per cluster (7.05 vs. 6.21) and wider leaves (14.1 vs. $13.18 \mathrm{~cm}$ ). Conversely, this group had the lowest leaf length/

Table 4. Correlation between the first five principal components and the quantitative variables of $T$. cacao $\mathrm{L}$. genotypes in Tumaco, Nariño.

\begin{tabular}{|c|c|c|c|c|c|}
\hline \multirow[b]{2}{*}{ Variables } & \multicolumn{5}{|c|}{ Variable-principal components correlation } \\
\hline & 1 & 2 & 3 & 4 & 5 \\
\hline Leaf length (LH) & 0.55 & -0.24 & 0.16 & -0.07 & 0.21 \\
\hline Leaf width $(\mathrm{AH})$ & 0.58 & -0.24 & 0.58 & 0.36 & 0.22 \\
\hline Leaf length/width ratio (RLAH) & -0.24 & 0.06 & -0.55 & -0.50 & -0.09 \\
\hline Amount of inflorescences per branch (CR) & 0.44 & -0.50 & 0.38 & -0.25 & 0.01 \\
\hline Flowers per inflorescence (FC) & 0.33 & -0.61 & 0.19 & -0.22 & -0.21 \\
\hline Staminode length (LE) & 0.41 & -0.30 & -0.36 & -0.09 & -0.04 \\
\hline Fruit length (LF) & 0.66 & 0.65 & 0.12 & -0.30 & 0.00 \\
\hline Fruit width (AF) & 0.32 & 0.57 & -0.12 & 0.36 & 0.47 \\
\hline Fruit length/width ratio (RLAF) & 0.45 & 0.24 & 0.24 & -0.64 & -0.41 \\
\hline Husk width (GC) & 0.33 & -0.14 & -0.23 & -0.15 & 0.68 \\
\hline Length of the pod arista (LAF) & 0.62 & 0.69 & 0.20 & -0.15 & -0.07 \\
\hline Seed fresh weight (PFG) & 0.63 & -0.03 & -0.36 & 0.46 & -0.37 \\
\hline Seed dry weight (PSG) & 0.45 & 0.03 & -0.32 & 0.50 & -0.54 \\
\hline Seed length (LG) & 0.65 & -0.49 & -0.29 & -0.08 & 0.05 \\
\hline Seed width (AG) & 0.45 & -0.08 & -0.58 & -0.23 & 0.26 \\
\hline Seeds per pod (GM) & 0.45 & 0.21 & -0.05 & 0.07 & 0.00 \\
\hline
\end{tabular}




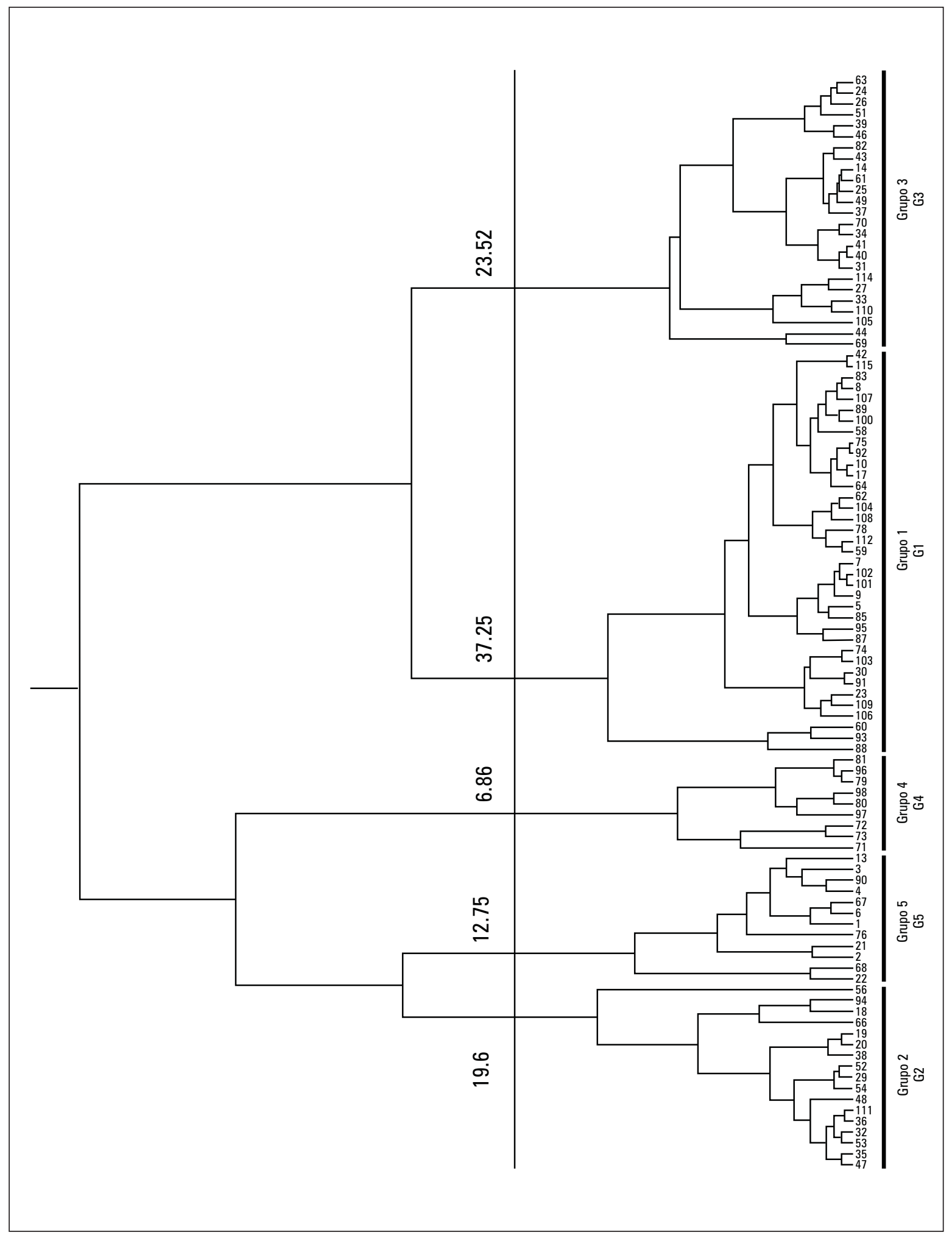

Figure 2. Dendrogram from the quantitative characteristics of the $T$. cacao L. genotypes. 
width ratio index (2.60 vs. 2.76), number of grains per pod (40.6 vs. 43.50), pod width (8.83 $v s .9 .53 \mathrm{~cm})$, length of the edge of the pod $(23.30$

vs. $25.35 \mathrm{~cm})$, and pod length (19.90 vs. 22.48 $\mathrm{cm})$. Therefore, this group was characterized by its smaller fruits and fewer grains per pod.

The third group (G3) made up 23.52\% of the genotypes, characterized by the highest amount of flowers per inflorescence (7.54 vs. 6.21), inflorescence per branch (18.83 vs. 16.96), leaf length (38.71 vs. $35.95 \mathrm{~cm}$ ), leaf width (14.29 vs.13.18 $\mathrm{cm}$ ), pod length/width ratio (2.55 vs. 2.36), pod length $(24.12 \mathrm{~cm} v s .22 .48 \mathrm{~cm})$, and number of grains per pod (45.6 vs. 43.5). Additionally, variables such as leaf width and staminode length showed the same superior characteristics.

The fourth group (G4) encompassed $6.86 \%$ of the population. It was characterized by trees with a greater pod diameter $(10.57$ vs. $9.53 \mathrm{~cm})$ and pod length edge $(25.35 \mathrm{vs} .25 .38 \mathrm{~cm})$. In contrast, variables such as staminode length (0.55 vs. $0.63 \mathrm{~cm}$ ), pod thickness (0.64 vs. $1.14 \mathrm{~cm})$, grain width $(0.57$ vs. $1.16 \mathrm{~cm})$ and grain length $(1.10 \mathrm{vs}$. $1.78 \mathrm{~cm}$ ) showed the lowest indexes.

The fifth group (G5) comprised $12.75 \%$ of the population. These genotypes were characterized by their higher leaf length/width ratio (3.05 vs. 2.76). Conversely, these cultivars showed lower averages for the other variables.

\section{Multiple correspondence analysis (MCA)}

The first five eigen values in the MCA explained $39.49 \%$ of the total variability (table 5 ). To explain $69.22 \%$ of the variability, 12 components were needed. The first three factors explained $26.96 \%$; the fourth and fifth factors explained $12.53 \%$ of the total variability.

The outstanding variables in the sampled genotypes were cacao trees with erect architecture (66 genotypes), vigorous (84), obtuse leaf base (59), leaf petiole with remarkable pulvinus (97), continuous flowering pattern with peaks (93), intense anthocyanin pigmentation in the staminodes (62), green pods when unripe (90), anthocyaninin ripe pods (93), flattened grains (65), and moderately resistant to $M$. roreri (90), and $C$. perniciosa (93).

The variables that contributed the most to the formation of axis one were the presence of anthocyanin in the ripe fruits(14.7\%), green pods when juvenile $(14.0 \%)$, absence of anthocyanin in the floral buds $(5.7 \%)$, green floral peduncle (5.1\%), low tree vigor (3.0\%), intermediate tree architecture (angle between $90^{\circ}$ and $135^{\circ}, 2.8 \%$ ), staminodes without anthocyanin(2.8\%), pods that were Angoleta-shaped (2.7\%), and pods with an attenuated apex (3.6\%).

Traits with higher contribution to the second axis were green color of the floral peduncle

Table 4. Eigen values of the correlation matrix and explained variance resulting from the MCA conducted for the qualitative characteristics.

\begin{tabular}{|c|c|c|c|}
\hline Component & Eigen value & Explained variance (\%) & Cumulative variance (\%) \\
\hline 1 & 0.18 & 10.59 & 10.59 \\
\hline 2 & 0.15 & 8.72 & 19.31 \\
\hline 3 & 0.13 & 7.65 & 26.96 \\
\hline 4 & 0.11 & 6.85 & 33.81 \\
\hline 5 & 0.10 & 5.68 & 39.49 \\
\hline
\end{tabular}


(6.5\%), long acuminated leaves (2.8\%), acute base of the leaves $(2.9 \%)$, pendulous plant architecture $(2.9 \%)$, lack of anthocyanin in the staminodes $(3.8 \%)$, cundeamor-shaped pods $(6.5 \%)$, pods with basal constriction and well-attenuated bottle neck (10.5\%), tolerance to frosty pot rot $(11.3 \%)$, and tolerance to witches' broom (9.2\%).

For the third axis, the traits that made significant contributions were leaf petiole without a noticeable pulvinus (5.3\%), plants with low vigor (8\%), trees with intermediate architecture (angle between $90^{\circ}$ and $1,351^{\circ}, 8.8 \%$ ), pods without basal constriction (5.4\%), and pods with obtuse apex (4\%).

The traits with the principal contribution to the fourth axis were leaf petiole without a noticeable pulvinus $(5.8 \%)$, green floral peduncle with reddish pigmentation (8.2\%), slight anthocyanin in the flower buds (10.3\%), absence of anthocyanin in the staminode $(4.7 \%)$, cundeamor-shaped pods $(5.9 \%)$, pods without basal constriction (3.7\%), attenuated shape of the pod apex (6.3\%), green pods when young (3.1\%), intermediate anthocyanin in the mature pods (4.3\%), and grains that were light violet (3.4\%).

The most important traits in the fifth axis were white beans (9.3\%), bottle-shaped pods in the basal constriction, intermediate bottle neck $(3.7 \%)$, pods that were amelonada-shaped $(7.8 \%)$, leaves with short-acuminate apex (10.8\%), and M. roreri (8.0\%) and C. perniciosa tolerance (10.1\%).

\section{Hierarchical classification of the qualitative traits of the T. cacao L. genotypes}

Using this procedure, we were able to rank the cultivars and group them into five clusters. The dendrogram (figure 3) shows the groups formed by the different genotypes. The first group was formed by $33.3 \%$ of the genotypes and was characterized as having cacao pods with a cundeamor shape (58\%), leaves with a pointed apex
(68\%), acute pod apex (57\%), slight presence of anthocyanin in the floral bud (51\%) and green pods when young (37.8\%). The second group consisted of $45.1 \%$ of the cultivars.

These trees were clustered based on the cundeamor pod shape (85.42\%), attenuated pod apex (75.51\%), accented bottle-shaped in the basal constriction (58.3\%), leaves with acute base (65.12\%), and pods without anthocyanin when ripe $(49.46 \%)$. The third group was formed by $7.84 \%$ of the genotypes. These trees were without a noticeable pulvinus and absent of anthocyanin in the staminodes (100\%), moderately susceptible to pod rot $(50 \%)$ and with an intermediate architecture (angle between $90^{\circ}$ and $135^{\circ}$ ). The fourth cluster comprised $3.92 \%$ of the genotypes. From these, $80 \%$ showed high tolerance to $C$. pernicios $a$ and $66.7 \%$ to $M$. roreri. Finally, the fifth group consisted of $9.8 \%$ of the genotypes. All of these trees had intermediate anthocyanin in the ripe pods, reddish tint in the unripe pods $(80 \%)$, intense anthocyanin pigmentation in the floral buds $(47 \%)$, reddish floral stalks $(20.93 \%)$, and angoleta-shaped pods (18\%).

\section{DISCUSSION}

This study revealed morphological variation among the cacao genotypes. The grain weight, pod size, type and index were higher in group One of the quantitative variables. Except for the characteristics of the floral clusters, all of the quantitative morphological traits were found useful for differentiating the cacao genotypes. This variability was also observed by Escobar (2008). Contrary to these findings, Arguello et al. (1999) in Bucaramanga, Colombia, in a PCA, needed 12 components to explain $72.9 \%$ of the variability. These reports indicate that these cacao crops tend to be homogeneous, which is a characteristic of cash crops. In this case, these trends were observed in the genotypes of the groups (G4 and G5) that showed some tolerance to the principal cacao diseases. 


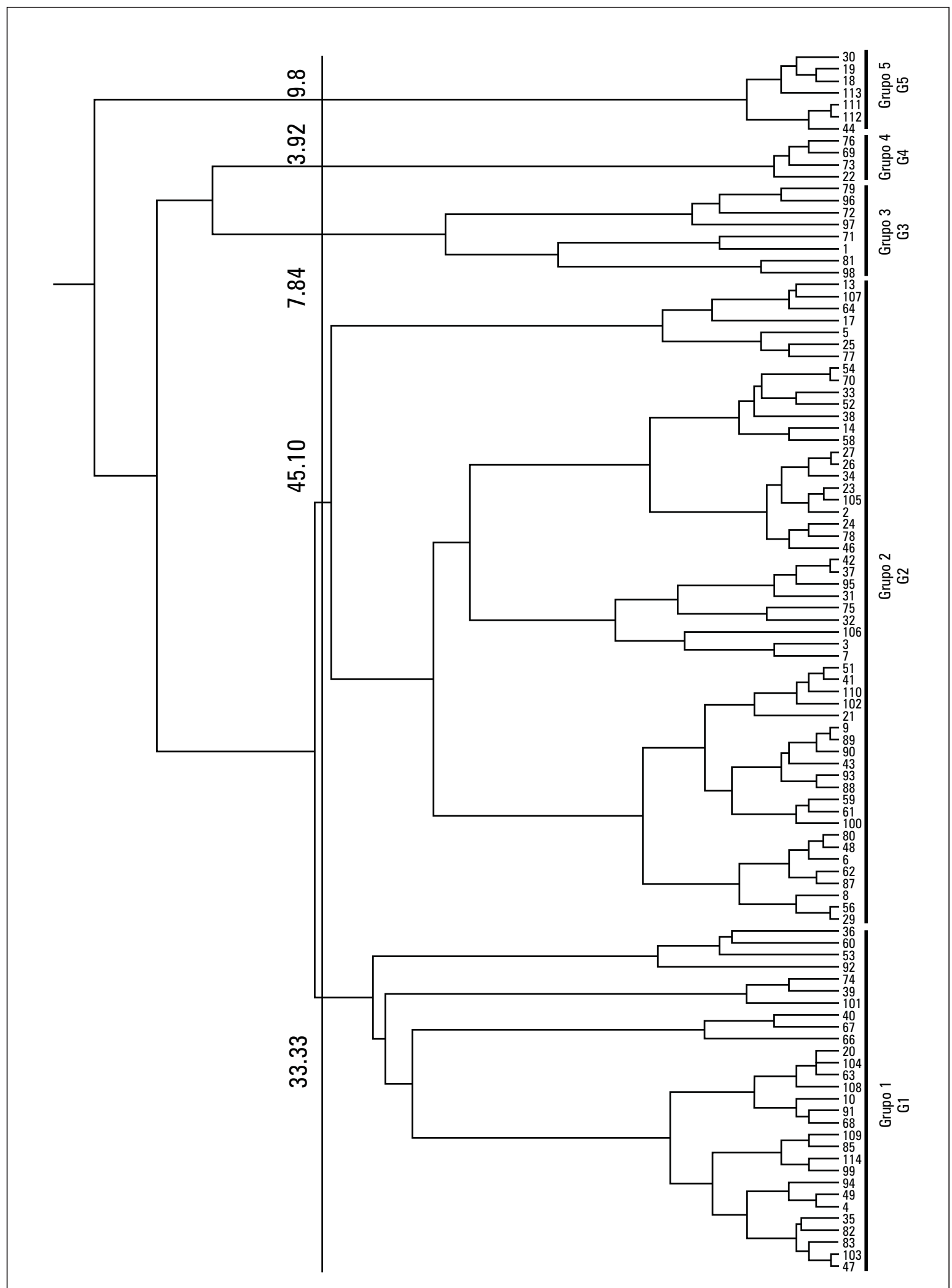

Figure 3. Hierarchical classification of the qualitative variables for the T. cacao L. genotypes in Tumaco. 
Considering the level of diversity of the traditional cacao varieties in Tumaco, foreign cultivars (i.e. CCN 51 clone) can considerably alter the characteristics of the local genotypes. Therefore, the external cacao interventions conducted by external institutions for growing new cacao genotypes can result in a reduction of the diversity existing in cacao crops over time.

There were no differences in the grain size (length and width) among the genotypes, which was observed in a previous study carried out on wild cacao trees from French Guiana (Lachenaud and Oliver, 1999). Morphological seed descriptors are not always able to discriminate among the groups of cacao accessions (Efombagn et al., 2009). The genetic diversity study carried out by Efombagn et al. (2000), with microsatellite markers, revealed that the diversity in cacao crops was genetically close to that of accessions maintained in germplasm banks.

Despite the low amount of flowers per tree, the characteristics associated with the productivity were higher in group G1. Other studies have already differentiated these traits among groups (Bekele et al., 2006). Some of these genotypes of group G1 might be of particular interest to cacao breeders because of their superior agronomic traits, such as grain and pod index and tolerance to $M$. roreri and C. perniciosa.

Variation based on pod traits might be associated with different morpho-geographic groups. Therefore, some of these variations among groups is due to the variation of the ecological conditions under which the cacao trees thrive. Efombagn et al. (2009) confirmed that the environment has a significant influence on the field performance of cacao genotypes.

Pod type was another qualitative trait that grouped the cacao genotypes. These descriptors were described as the most useful for studying the variability of cacao populations (Engels, 1983; Bekele and Bekele, 1996; Lachenaud et al., 1999).
In Tumaco, besides productivity of the regional genotypes, tolerance to diseases is another goal of the cacao breeders and producers. Genes controlling for agronomic traits such as resistance to frosty pot rot and witches' broom are conserved in traditional cacao farms over several decades through cacao growing practices (Efombagn et al., 2009) and it is important for biodiversity and genetic conservation. Locally, farmers usually achieve this by selecting pods from their neighboring crops (Efombagn et al., 2009). Quantitative studies of other cacao organs, such as leaves, and plant growth were found to not be important discriminative factors, as reported by Ostendorf (1965) and De Almeida and Valle (2008).

FEDECACAO (2004) studied the physical and chemical parameters of the cacao grain. They determined grains with a dry weight greater than $1.2 \mathrm{~g}$ were considered large and optimum for industrialization. The smaller fruits and the low weight of the seeds may be an indicator of low quality for cacao growers when selecting cultivars of cacao. Since the regional market has standards for high quality in cacao grains (Icontec, 2003), cultivars with small grains are not favored.

These results are similar to that found by Pound (1996), who concluded that the dry weight of the seed is the most reliable trait for the description and identification of a genotype of cacao. Adewale et al. (2014) corroborated these results by affirming the number of seeds per pod and dry weight are the best descriptors of cacao productivity. Similarly, Quiroz and Soria (1994) and Soria (1996) observed that variables related to pod size were the most important discriminators for nacional cacao of Ecuador and the Amazon.

In the PCA, the first five components explained $70.17 \%$ of the total variability; the factors that contributed the most to the variability were related to the fruit, edge length, thickness of the shell and width/length ratio of the fruit. In the MCA, the first five values accounted for $39.5 \%$ of the variability. These factors included vari- 
ables related to color and shape of the fruits, flowers, and tolerance to $M$. roreri and C. perniciosa. In the hierarchical classification of the quantitative variables, group One and group Three were formed by genotypes with a greater size, quantity and weight of seed and fruit size, while groups Two and Four stood out by having cundeamor fruits with an attenuated apex, bottleshaped basal constriction and high tolerance to $M$. roreri and C. perniciosa.

A wide variability in the components of performance, characteristic morphology of fruits and seeds, and tolerance to $M$. roreri and C. perniciosa existed in the evaluated genotypes, as cited by Ji et al., (2012) when studying farmer varieties of cacao in Honduras and Nicaragua. In the studied population, $81.1 \%$ presented pod and grain indicators of good agronomic and industrial properties.

Similar characteristics were identified by Graziani de Fariñas et al. (2002) for creole cultivars, indicating that $53 \%$ of the analyzed fruits belonged to angoleta and $28 \%$ to cundeamor. Ortiz de Bertorelli and Graziani de Farinas (1995) pointed out that, in creole cacao genotypes of Aragua, calabacillo and angoleta, basal constriction prevailed. On the other hand, Sánchez and Tortolero (1996) found fruits of Criollo cacao with great diversity in shape, color, and texture in littoral Aragüeño.

They attributed it to mixtures mostly from external related criollos. Diverse gradation of colors, red, green, yellow, and intermediate, were observed by Graziani de Fariñas et al., (2002). The color is controlled by a pair of genes leading to the presence of a red pigment (R), green $(\mathrm{r})$, and dominant recessive (Enríquez and Soria, 1981). Besides color diversity, Graziani de Farinas et al. (2002), in Venezuela, found contrasting physical characteristics of the fruits of crio1lo, trinitario, and other external types from the town of Cumboto. These findings were reported as well by Loor et al. (2009) in Ecuador.

\section{CONCLUSIONS}

In this study, using the morphological traits, 75 genotypes of regional cacao were selected as elites in Tumaco. These genotypes showed a high level variability in the quantitative and qualitative traits that have been considered as desirable traits for a breeding program (Chumacero de Schawe et al., 2013). These traits were number of grains per pod, dry weight of grains, pod size, leaf size, and tolerance to $M$. roreri and C. perniciosa.

In the selection process of cacao in Tumaco, it is therefore advised to improve the seed and pod size by exploiting these genotypes with favorable characteristics. However, such quantitative and polygenic traits are under strong environmental influence (Dos Santos-Dias et al., 2003). The stability of such quantitative traits should be studied using molecular markers (Lerceteau et al., 1997; Londoño et al., 2011) to generate reliable and reproducible data under different regional ecological conditions (Engels, 1993).

These selected genotypes have to be preserved in clonal gardens for future evaluations. In a forthcoming breeding program, other phenotypic traits of agronomic interest may include number of pods, resistance to pest and diseases, and flavor and taste analysis, as reported by Marcano et al. (2009).

\section{ACKNOWLEDGEMENTS}

The author would like to acknowledge financial support from the University of Nariño and the Consejos Comunitarios of Robles and Rosario and to thank the farmers who participated in this research. 


\section{BIBLIOGRAPHIC REFERENCES}

Adewale, D.B., O.O. Adeigbe., O.L. Sobowale, and D.S Dada. 2014. Breeding value of cocoa (Theobroma cacao L.) for pod and bean traits: A consequential advance in Nigerian cocoa breeding program. Not. Sci. Biol. 6(2), 214-219

Aranzazu, F. and A. Agudelo, A. 2009. Reunión regional de cacaoteros. Formulación del plan de desarrollo departamental de Nariño. Tumaco, Colombia.

Arguello, C.O., F.L. O. Mejía, N. Contreras, and J. Toloza. 1999. Evaluación, introducción y multiplicación de Árboles elite de cacao como estrategia de productividad para el nororiente Colombiano. Informe final proyecto. Corpocia, Bucaramanga, Colombia.

Ayestas, E., L. Orozco, C. Astorga, R.M. Unguía, and C. Vega. 2013. Caracterización de árboles promisorios de cacao en fincas orgánicas de Waslala, Nicaragua. Agroforestería en las Américas (49), 18-25

Ballesteros P., W. 2011. Caracterización morfológica de árboles élite de cacao (Theobroma cacao L.) en el municipio de Tumaco, Nariño, Colombia. M.Sc thesis. Faculty of Agricultural Sciences, Universidad de Nariño, Pasto, Colombia.

Bekele, F.L and I. Bekele. 1996. A sampling of the phenetic diversity of cacao in the international Cacao Gene Bank of Trinidad. Crop Sci. 36 (1):57-64.

Cartay, R. 1997. La economía del cacao en Venezuela. pp. 129-146. In: Proc. I Congreso Venezolano del Cacao y su Industria. Maracay, Venezuela.

Casa Luker. 2012. Cacao fino de aroma. http://www. lukeringredients.com/en/home; consulted: January, 2016.

Chessman, E.E. 1944. Notes on the nomenclature, classification and possible relationships of cocoa populations. Trop. Agr. 21, 144-159. Doi: 10.1038/ hdy.1994.166

Chumacero de Schawe, C., W. Durka, T. Tscharntke, I. Hensen, and M. Kessler. 2013. Gene flow and genetic diversity in cultivated and wild cacao (Theobroma cacao) in Bolivia. Am. J. Bot. 100, 2271-2279. Doi: 10.3732/ajb.1300025

Clement, C.R., M. de Cristo-Araújo., G.C. d'Eeckenbrugge, A. Alves Pereira, and D. PicançoRodrigues. 2010. Origin and domestication of na- tive Amazonian crops. Diversity 2, 72-106. Doi: 10.3390/d2010072

De Almeida, A.A.F. and R.R. Valle. 2007. Ecophysiology of the cacao tree. Braz. J. Plant Physiol 19(4), 425448

Dos Santos-Dias, L.A., J.P. Barriga, P.Y. Kageyama, and M.V. Cordeiro de Almeida. 2003. Variation and its distribution in wild cacao populations from the Brazilian Amazon. Braz. Arch. Biol. Technol. 46(4), 507-514.

Efombagn, M.I.B., O. Sounigo, M. Nyasse, M. Manzanares-Dauleu, and A.B. Eskes. 2009. Phenotypic variation of cacao (Theobroma cacao L.) on farms and in the gene bank in Cameroon. J. Plant Crop Sci. 1(6), 258-264

Engels, J.N. 1986. The identification of cacao cultivars. Acta Hortic.182, 195-203. Doi: 10.17660/ActaHortic.1986.182.23

Engels, J.N., B.G. Bartley, and G. Enriquez. 1980. Cacao descriptors, their states and modus operandi. Turrialba 30(2), 209-218

Engels, J.M.M. 1993. The use of botanical descriptors for cacao characterization. CATIE experiences. pp. 69-76. In: Proceedings of the international workshop on conservation, characterization and utilization of cacao genetic resources in the 21th Century. The Cacao Research Unit, Trinidad.

Enríquez, G.A. and J. Soria. 1981. Internacional cacao cultivar catalogue. Technical Bulletin No 6. Centro Agronómico Tropical de Investigación y Enseñanza (CATIE), Turrialba, Costa Rica.

Escobar, J.E. 2008. Caracterización morfológica in situ de árboles regionales sobresalientes de cacao Theobroma cacao L, en los núcleos productivos del municipio de Tumaco - Nariño. Undergraduate thesis. FACIA, Universidad de Nariño, Pasto, Colombia.

Fedecacao. 2004. Beneficio y características físico químicas del cacao (Theobroma cacao L). Fondo Nacional del Cacao, Produmedios, Bogotá.

Graziani de Farinas, L., L. Ortiz de Bertorelli, J. Angulo, and P. Parra. 2002. Características físicas del fruto de cacaos tipos criollo, forastero y trinitario de la localidad de Cumboto, Venezuela. Agronomía Trop. 52(3), 343-362. 
Holdridge, L. 1987. Ecología basada en zonas de vida. Instituto Interamericano de Cooperación para la Agricultura, San José, Costa Rica.

ICCO (International Cacao Organization). 2016. Decreto ICC/71/7 Características del cacao fino y de aroma. http://www.icco.org/about-cacao/fine-orflavour-cacao.html; consulted: January, 2016.

ICCO (International Cacao Organization). 2014. Latest Quarterly Bulletin of Cacao Statistic. http:// www.icco.org/statistics/quarterly-bulletin-cocoastatistics.html; consulted: January, 2016.

Icontec. 2003. Cacao en grano. Norma técnica Colombiana 1252. Instituto Colombiana de Normas Técnicas y Certificación, Bogotá.

Ji, K., D. Zhang, L.A. Motilal, M. Boccara, P. Lachenaud, and L.W. Meinhardt. 2012. Genetic diversity and parentage in farmer varieties of cacao (Theobroma cacao L.) from Honduras and Nicaragua as revealed by single nucleotide polymorphism (SNP) markers. Genet. Resour. Crop Evol. 60: 441-453. Doi: 10.1007/s10722-012-9847-1

Lachenaud, P., F. Bonnot, and G. Oliver. 1999. Use of floral descriptors to study variability in wild cacao trees (Theobroma cacao L) in French Guiana. Genet Resour. Crop. Evol. 46, 491-500.

Lerceteau, E., J. Quiroz, J. Soria, S. Flipo, V. Pétiard, and D. Crouzilat.1997. Genetic differentiation among Ecuadorian Theobroma cacao L. accessions using DNA and morphological analyses. Euphytica 95, 77-87. Doi: 10.1023/A:1002993415875

Londoño M., J., D.M. Gil V., S.B. Aguilar M., F.A. Rivera P., and G.A. López G. 2011. Caracterización molecular de clones de Theobroma cacao L., por medio de marcadores moleculares microsatélites. Luna Azul 32:52-60. Doi: 10.17151/luaz.2011.32.6

Loor, R.G., A.M. Risterucci, B. Courtois, O. Fouet, M. Jeanneau, E. Rosenquist, F. Amores, A. Vasco, M. Medina, and C. Lanaud. 2009. Tracing the native ancestors of the modern Theobroma cacao L. population in Ecuador. Tree Genet. Genomes 5, 421433. Doi: 10.1007/s11295-008-0196-3

Marcano, M., S. Morales, M.T. Hoyer, B. Courtois, A.M. Risterucci, O. Fouet, T. Pugh, E. Cros, V. Gonzalez, M. Dagert, and C. Lanaud. 2009. A genomewide admixture mapping study for yield factors and morphological traits in a cultivated cocoa (Theobroma cacao L.) population. Tree Genet. Genomes 5, 329-337. Doi: 10.1007/s11295-008-0185-6

Morillo, C.Y., A.C. Morillo., J.E. Muñoz F., W. Ballesteros P., and A. González. 2014. Molecular characterization of 93 genotypes of cocoa (Theobroma cacao
L.). Agron. Colomb. 32(3), 315-325. Doi: 0.15446/ agron.colomb.v32n3.46879

Motamayor, J.C., A.M. Risterucci., P.A. López., C.F. Ortiz., A. Moreno., C. Lanaud. 2002. Cacao domestication. In: The origin of the cacao cultivated by the Mayas. Heredity 89, 380-386. doi:10.1038/ sj.hdy. 6800156

Motamayor, J.C., P. Lachenaud, J.W. da Silva e Mota, R. Loor, D.N. Kuhn, J.S. Brown, and R.J. Schnell. 2008. Geographic and genetic population differentiation of the Amazonian chocolate tree (Theobroma cacao L). 3(10): 1-8. Doi: 10.1371/journal. pone.0003311

Motilal, L.A., D. Zhang, P. Umaharan, S. Mischke, V. Mooleedhar, and L.W. Meinhardt. 2010. The relic Criollo cacao in Belize - genetic diversity and relationship with Trinitario and other cacao clones held in the International Cocoa Genebank, Trinidad. Plant Genet. Resour. 8, 106-115. Doi: 10.1017/ S1479262109990232

N'Goran, J.A.K., V. Laurent., A.M. Risterucci, and C. Lanaud. 1994. Comparative genetic diversity studies of Theobroma cacao L. using RFLP and RAPD markers. Heredity (1994) 73, 589-597. Doi: 10.1038/hdy.1994.166

Ortiz de Bertorelli, L. and L. Graziani de Farinas. 1995. Caracterización física y química de genotipos de cacao en el estado Aragua. Instituto de química y Tecnología. Facultad de Agronomía, Universidad Central de Venezuela, Maracay, Venezuela.

Ostendorf, F.W. 1965. Identifying characters for cacao clones crop. pp. 89-110. In: Reuniao do Comité Técnico Interamericano do Cacau, VI Salvador, Bahía, Brasil.

Pound, F.J. 1996. The genetic constitution of the cacao Crop. pp. 27-29. In: Annual report on Cacao Research. Imperial College of Tropical Agriculture, Trinidad.

Preciado, O., C.I. Ocampo, and W. Ballesteros Possú. 2011. Caracterización del sistema tradicional de producción de cacao (Theobroma cacao L.), en seis núcleos productivos del municipio de Tumaco, Nariño. Revista de Ciencias Agrícolas 28(2), 58-69.

Quiroz, J. and J. Soria, J. 1994. Caracterización fenotípica del Cacao Nacional del Ecuador. Quito, Ecuador. Boletín Técnico No. 74. INIAP, Estación Experimental Tropical Pichilingue, Quevedo-El Empalme, Ecuador.

Sánchez, A. and L. Tortolero. 1996. Caracterización y establecimiento de un Banco de Germoplasma de cacao criollo en el litoral aragüeño. Informe Final. 
Fondo Nacional de Investigaciones Agropecuarias (FONAIAP), Estación Experimental del Estado Miranda, Venezuela.

Sánchez, I., L.A. Zárate, G. Gallego, and J. Tohme. 2007. Análisis de la diversidad genética de accesiones de Theobroma cacao L. del banco de conservación a cargo de Corpoica. Corpoica Cienc. Tecnol. Agropecu. 8(2): 26-31

Soria, V.J. 1969. Principales variedades de cacao cultivadas en América Tropical. Turrialba 16(3), 261265.

Thomas E., M. van Zonneveld, J. Loo., T. Hodgkin, G. Galluzzi, and J. van Etten. 2012. Present spatial diversity patterns of Theobroma cacao L. in the Neotropics reflect genetic differentiation in pleistocene refugia followed by human-influenced dispersal. PLoS ONE 7(10). Doi: 10.1371/journal. pone.0047676

Vallejo, G. and E. Peña. 2006. Centro Regional de Investigación el Mira. Plegable promocional $N^{\circ} 47$. Corpoica, Tumaco, Colombia.

Zhang, D., W.J. Martínez, E.S. Johnson, E. Somarriba, W. Phillips-Mora, C. Astorga, S. Mischke, and L.W. Meinhardt. 2012. Genetic diversity and spatial structure in a new distinct Theobroma cacao L. population in Bolivia. Genet. Res. Crop Evol. 59, 239-252. Doi: 10.1007/s10722-011-9680-y

Zhang, D., S. Mischk, S.E. Johnson, W. Phillips-Mora, and L. Meinhardt. 2008. Molecular characterization of an international cacao collection using microsatellites markers. Tree Genet. Genomes 5, 1-10. Doi: 10.1007/s11295-008-0163-z 